\title{
Motor nerve conduction study in patients on diphenylhydantoin therapy ${ }^{1}$
}

\author{
S. CHOKROVERTY ${ }^{2}$ AND Z. A. SAYEED ${ }^{3}$ \\ From the Neurology Service and Neurology Research Laboratory, VA Hospital, Hines, Illinois, Cook County \\ Hospital, Chicago, Illinois, and the Department of Neurology, The Chicago Medical School, Chicago, Illinois, \\ U.S.A.
}

SYNOPSIS Mean motor conduction velocity of posterior tibial nerves was significantly reduced in epileptic patients treated with diphenylhydantoin for more than 10 years or in patients with serum diphenylhydantoin level above $20 \mu \mathrm{g} / \mathrm{ml}$. Subnormal serum folate was not responsible for this reduction and clinical peripheral neuropathy was infrequent.

There have been recent indications of direct toxic effects of diphenylhydantoin (DPH) on human peripheral nerve (Hopf, 1968; Lovelace and Horwitz, 1968; Birket-Smith and Krogh, 1971; DeCastro et al., 1972; Encinoza, 1974; Eisen et al., 1974), although these have been noted in experimental animal studies in the past (Toman, 1949; Korey, 1951; Morrell et al., 1958). In the report by Hopf (1968) and Lovelace and Horwitz (1968), the conduction velocity study was not correlated with serum DPH levels. Birket-Smith and Krogh (1971) studied only patients whose DPH level was above $20 \mu \mathrm{g} / \mathrm{ml}$. Although Eisen and associates correlated peripheral nerve conduction velocity study with DPH level, their study was restricted to patients receiving DPH for ten or more years. We are now reporting a study of peripheral motor nerve conduction velocities correlated with clinical states and serum levels of DPH, folate and cyanocobalamin in epileptic patients who had been on DPH treatment for one to 27 years. Our report contains certain observations which differ somewhat from those in the previous publications.

\footnotetext{
1 Presented in part at the 20th Annual Meeting of the Amerizan Association of Electromyography and Electrodiagnosis, Boston, Massachusetts, April 1973.

2 Present address: P.O. Box 127, Hines, Illinois 60141 U.S.A.

3 Present address: Institute of Neurology, Madras, India.

(Accepted 15 July 1975.)
}

\section{METHODS}

Patients were selected at random from the adult epilepsy clinic of a large county hospital. There were 13 men and 22 women between the ages of 17 and 58 with a mean of 33 years. We have excluded from this study patients over the age of 60 years and those with diabetes mellitus, renal, hepatic, and obvious neuromuscular disorders, or with a history of alcoholism. All patients received additional anticonvulsant drugs. A careful neurological examination was made in every patient. These 35 patients received 300 to $400 \mathrm{mg}$ DPH daily in three divided doses for one to 27 years. Nystagmus was present in 22 patients. Cerebellar ataxia was demonstrated in three patients. Motor function and sensation were normal in all, while three patients had absent ankle reflexes. Blood was withdrawn for determination of serum DPH, folate and cyanocobalamin levels and blood glucose and haemoglobin. Serum DPH was measured by gas-liquid chromatography.

MOTOR NERVE CONDUCTION STUDY We have measured motor nerve conduction velocities of ulnar and posterior tibial nerves bilaterally according to the standard method using surface electrodes and a Teca TE-4 electromyograph. These studies were performed within one to two hours of withdrawal of blood for the aforementioned laboratory data. A bipolar stimulating electrode was used delivering square wave electric pulses of 0.05 to $0.5 \mathrm{~ms}$ duration applied with cathode distally at the rate of one per second. The ulnar nerve was stimulated supramaximally at the elbow and wrist with a pick-up electrode over the abductor digiti quinti muscle. The indiff- 
erent electrode was placed over the little finger. The resulting action potential was amplified, displayed on the oscilloscope, and photographed on the recording paper by means of a high speed direct recorder which was incorporated into the equipment. Latencies were measured from the stimulus artefact to the onset of the evoked potential. The distance between the cathodal stimulating points was measured carefully in centimetres. This distance divided by the conduction time (in ms) allowed computation of the conduction velocity of the fastest motor fibres in metres per second. The motor conduction velocity of the posterior tibial nerve was similarly measured by supramaximal stimulation of the nerve in the popliteal fossa and at the ankle medial to the medial malleolus, and the evoked potential was picked up by the recording electrode placed at the abductor digiti quinti muscle of the foot. Examination was performed at room temperature of $22-24.4^{\circ} \mathrm{C}$.

\section{RESULTS}

In Table 1 the relationship between DPH treatment and absent ankle reflexes, nystagmus, and mean serum DPH levels is shown. Absent ankle reflexes were related to the duration of DPH treatment. Furthermore, two patients with absent

TABLE 1

RELATIONSHIP BETWEEN DPH THERAPY AND ANKLE REFLEXES, NYSTAGMUS AND SERUM DPH LEVEL IN 35 PATIENTS

\begin{tabular}{|c|c|c|c|c|c|}
\hline \multirow{2}{*}{$\begin{array}{l}\text { Duration } \\
\quad(y r)\end{array}$} & \multirow[t]{2}{*}{ Patients } & \multicolumn{2}{|c|}{ Reflexes } & \multirow[t]{2}{*}{ Ny'stagmus } & \multirow{2}{*}{$\begin{array}{c}\text { Mean serum } \\
\text { diphenylhydantoin } \\
\text { in cach group } \\
(\mu \mathrm{g} / \mathrm{ml})\end{array}$} \\
\hline & & $\begin{array}{c}\text { Normal } \\
\text { (no.) }\end{array}$ & $\begin{array}{c}\text { Absent } \\
\text { (no.) }\end{array}$ & & \\
\hline $\begin{array}{c}1-5 \\
6-10 \\
11-15 \\
16-20 \\
21-27 \\
\text { Total }\end{array}$ & $\begin{array}{r}9 \\
10 \\
5 \\
4 \\
7 \\
35\end{array}$ & $\begin{array}{r}9 \\
10 \\
4 \\
4 \\
5 \\
32\end{array}$ & $\begin{array}{l}0 \\
0 \\
1 \\
0 \\
2 \\
3\end{array}$ & $\begin{array}{r}6 \\
5 \\
4 \\
2 \\
5 \\
22\end{array}$ & $\begin{array}{l}15.7 \\
17.6 \\
28.7 \\
12 \\
24.3\end{array}$ \\
\hline
\end{tabular}

TABLE 2

RELATION BETWEEN NYSTAGMUS AND SERUM DIPHENYLHYDANTOIN (DPH) LEVEL

\begin{tabular}{lllllll}
\multicolumn{1}{c}{$\begin{array}{c}\text { DPH level } \\
(\mu \mathrm{g} / \mathrm{ml})\end{array}$} & $M$ & $S E$ & $M_{D}$ & $S E_{D}$ & $t$ & $P$ \\
\hline Patients with nystagmus & 23.6 & 1.9 & 11.9 & 2.6 & 4.6 & $<0.05$ significant \\
Patients without nystagmus & 11.7 & 2 & & & &
\end{tabular}

$M$ : Mean; SE: Standard error; $M_{D}$ : Mean difference; $S_{D}$ : Standard error of mean difference.

TABLE 3

RELATION BETWEEN DURATION OF DIPHENYLHYDANTOIN THERAPY AND SERUM CYANOCOBALAMIN AND FOLATE LEVELS

\begin{tabular}{|c|c|c|c|c|c|c|c|c|}
\hline & \multicolumn{4}{|c|}{ Duration } & \multirow[b]{3}{*}{$M_{D}$} & \multirow[b]{3}{*}{$S E_{D}$} & \multirow[b]{3}{*}{$t$} & \multirow[b]{3}{*}{$P$} \\
\hline & \multicolumn{2}{|c|}{$10 y r$ or $<10$} & \multicolumn{2}{|c|}{$>10 \mathrm{yr}$} & & & & \\
\hline & $M$ & $S E$ & $M$ & $S E$ & & & & \\
\hline $\begin{array}{l}\text { Serum cyanocobalamin } \\
\text { Serum folate }\end{array}$ & $\begin{array}{r}514.5 \\
7.1\end{array}$ & $\begin{array}{r}49.6 \\
0.6\end{array}$ & $\begin{array}{r}543.9 \\
5.1\end{array}$ & $\begin{array}{r}55.7 \\
0.5\end{array}$ & $\begin{array}{c}-29.4 \\
2\end{array}$ & $\begin{array}{c}74 \\
0.8\end{array}$ & $\begin{array}{l}0.4 \\
2.5\end{array}$ & $\begin{array}{l}>0.05 \mathrm{NS} \\
<0.05 \text { significant }\end{array}$ \\
\hline
\end{tabular}

$M$ : Mean; $S E$; Standard error; $M_{D}$ : Mean difference; $S_{D}$ : Standard error of mean difference.

Serum cyanocobalamin level expressed in $\mathrm{pg} / \mathrm{ml}$ (normal: $200-900)$. Serum folate level expressed in $\mathrm{ng} / \mathrm{ml}$ (normal:

6-16). 
TABLE 4

RELATION BETWEEN DURATION OF DIPHENYLHYDANTOIN THERAPY AND NERVE CONDUCTION VELOCITIES (M/S)

\begin{tabular}{|c|c|c|c|c|c|c|c|c|}
\hline \multirow[t]{2}{*}{ Nerie } & \multicolumn{2}{|c|}{ Up to 10 years } & \multicolumn{2}{|c|}{ More than 20 years } & \multirow[t]{2}{*}{$M_{D}$} & \multirow[t]{2}{*}{$S E_{D}$} & \multirow[t]{2}{*}{$t$} & \multirow[t]{2}{*}{$P$} \\
\hline & $\bar{M}$ & $\overrightarrow{S E}$ & $M$ & $S E$ & & & & \\
\hline $\begin{array}{l}\text { Ulnar } \\
\text { Posterior tibial }\end{array}$ & $\begin{array}{l}52.3 \\
45.2\end{array}$ & $\begin{array}{l}1.6 \\
1.5\end{array}$ & $\begin{array}{l}52.9 \\
42\end{array}$ & $\begin{array}{l}1.2 \\
0.8\end{array}$ & $\begin{array}{r}-0.6 \\
3.2\end{array}$ & $\begin{array}{l}2 \\
1.4\end{array}$ & $\begin{array}{l}0.3 \\
2.3\end{array}$ & $\begin{array}{l}>0.05 \mathrm{NS} \\
<0.05 \text { significant }\end{array}$ \\
\hline
\end{tabular}

$M$ : Mean; SE: Standard error; $M_{D}$ : Mean difference; $\mathrm{SE}_{\mathrm{D}}$ : Standard error of mean difference.

TABLE 5

MOTOR NERVE CONDUCTION VELOCITIES (M/S) IN TWO GROUPS OF PATIENTS

\begin{tabular}{|c|c|c|c|c|c|c|c|c|}
\hline \multirow[t]{3}{*}{ Nerie } & \multicolumn{4}{|c|}{ Age (yr) } & \multirow[b]{3}{*}{$M_{D}$} & \multirow[b]{3}{*}{$S E_{D}$} & \multirow[b]{3}{*}{$t$} & \multirow[b]{3}{*}{$P$} \\
\hline & \multicolumn{2}{|c|}{$17-35$} & \multicolumn{2}{|c|}{$36-58$} & & & & \\
\hline & $M$ & $S E$ & $M$ & $S E$ & & & & \\
\hline $\begin{array}{l}\text { Posterior tibial (right) } \\
\text { Ulnar (right) }\end{array}$ & $\begin{array}{l}44 \\
52.9\end{array}$ & 1.3 & $\begin{array}{l}44 \\
50.5\end{array}$ & $\begin{array}{l}1.2 \\
1.2\end{array}$ & $\begin{array}{l}0 \\
2.4\end{array}$ & $\begin{array}{l}1.6 \\
1.3\end{array}$ & $\begin{array}{l}0 \\
1.8\end{array}$ & $\left.\begin{array}{l}>0.05 \\
>0.05\end{array}\right\} \mathrm{NS}$ \\
\hline
\end{tabular}

$M$; Mean; $S E$ : Standard error; $M_{D}$ :Mean difference; $S E_{D}$ : Standard error of mean difference.

TABLE 6

RELATION BETWEEN SERUM DIPHENYLHYDANTOIN (DPH) LEVEL AND NERVE CONDUCTION VELOCITIES $(\mathrm{M} / \mathrm{S})$

\begin{tabular}{|c|c|c|c|c|c|c|c|c|}
\hline \multirow[t]{3}{*}{ Nerve } & \multicolumn{4}{|c|}{ Serum $D P H$} & \multirow[b]{3}{*}{$M_{D}$} & \multirow[b]{3}{*}{$S E_{D}$} & \multirow[b]{3}{*}{$t$} & \multirow[b]{3}{*}{$P$} \\
\hline & \multicolumn{2}{|c|}{20 or $<20 \mu \mathrm{g} / \mathrm{ml}$} & \multicolumn{2}{|c|}{$>20 \mu \mathrm{g} / \mathrm{ml}$} & & & & \\
\hline & $M$ & $S E$ & $M$ & $S E$ & & & & \\
\hline $\begin{array}{l}\text { Ulnar } \\
\text { Posterior tibial }\end{array}$ & $\begin{array}{l}512 \\
44.2\end{array}$ & $\begin{array}{l}1 \\
1.1\end{array}$ & $\begin{array}{l}52.8 \\
41.6\end{array}$ & $\begin{array}{l}1.2 \\
1\end{array}$ & $\begin{array}{r}-1.6 \\
2.6\end{array}$ & $\begin{array}{l}1.3 \\
1.3\end{array}$ & $\frac{1.2}{2}$ & $\begin{array}{l}>0.05 \mathrm{NS} \\
<0.05 \text { significant }\end{array}$ \\
\hline
\end{tabular}

$M$ : Mean; SE: Standard error; $M_{D}$ : Mean difference; $S_{D}$ : Standard error of mean difference.

ankle reflexes revealed high serum DPH levels (30 $\mu \mathrm{g}$ and $40 \mu \mathrm{g} / \mathrm{ml}$ ) but one had DPH in the therapeutic range $(15 \mu \mathrm{g} / \mathrm{ml})$. Table 2 shows the relation between nystagmus and serum DPH level. The mean serum DPH level in patients with nystagmus was significantly higher (23.6 $\mu \mathrm{g} / \mathrm{ml})$ than the mean $(11.7 \mu \mathrm{g} / \mathrm{ml})$ in patients without nystagmus. Table 3 shows the relation between the duration of DPH treatment and serum cyanocobalamin and folate levels. Serum cyanocobalamin levels were normal in all patients and were not significantly altered with prolonged use of DPH. However, subnormal values for serum folate were noted in patients who had been on DPH treatment for more than 10 years. Table 4 shows the relation between the duration of DPH treatment and motor nerve conduction velocities. The duration is divided into two groups: (a) up to 10 years, and (b) more than 10 years. We did not note any significant difference between the ulnar nerve conduction velocities in these two groups, but the posterior tibial nerve conduction velocity was significantly lower in patients who had been on DPH treatment for more than 10 years. Absolute values of posterior tibial nerve conduction velocities in patients with absent ankle reflexes were slightly below normal $(35,36$, and $38 \mathrm{~m} / \mathrm{s})$. 
TABLE 7

RELATION BETWEEN SERUM FOLATE LEVEL AND NERVE CONDUCTION VELOCITIES $\left(\mathrm{M}_{i} / \mathrm{S}\right)$

\begin{tabular}{|c|c|c|c|c|c|c|c|c|}
\hline \multirow[t]{2}{*}{ Nerte } & \multicolumn{4}{|c|}{ Serum folate } & \multirow{2}{*}{$M_{D}$} & \multirow{2}{*}{$S E_{D}$} & \multirow{2}{*}{$t$} & \multirow{2}{*}{$P$} \\
\hline & \multicolumn{2}{|c|}{$<7 \mathrm{ng} / \mathrm{ml}$} & \multicolumn{2}{|c|}{7 or $>7 \mathrm{ng} / \mathrm{ml}$} & & & & \\
\hline $\begin{array}{l}\text { Ulnar } \\
\text { Posterior tibial }\end{array}$ & $\begin{array}{l}50.7 \\
42.2\end{array}$ & $\begin{array}{l}1.3 \\
0.6\end{array}$ & $\begin{array}{l}51.6 \\
43\end{array}$ & $\begin{array}{l}0.8 \\
1.1\end{array}$ & $\begin{array}{l}-0.9 \\
-0.8\end{array}$ & $\begin{array}{l}1.5 \\
1.2\end{array}$ & $\begin{array}{l}0.6 \\
0.6\end{array}$ & $\left.\begin{array}{l}>0.05 \\
>0.05\end{array}\right\} \mathrm{NS}$ \\
\hline
\end{tabular}

$M$ : Mean; $S E$ : Standard error; $M_{D}$ : Mean difference; $S_{D}$ : Standard error of mean difference.

TABLE 8

RELATION BETWEEN SERUM $B_{12}$ LEVEL AND NERVE CONDUCTION VELOCITIES (M/S)

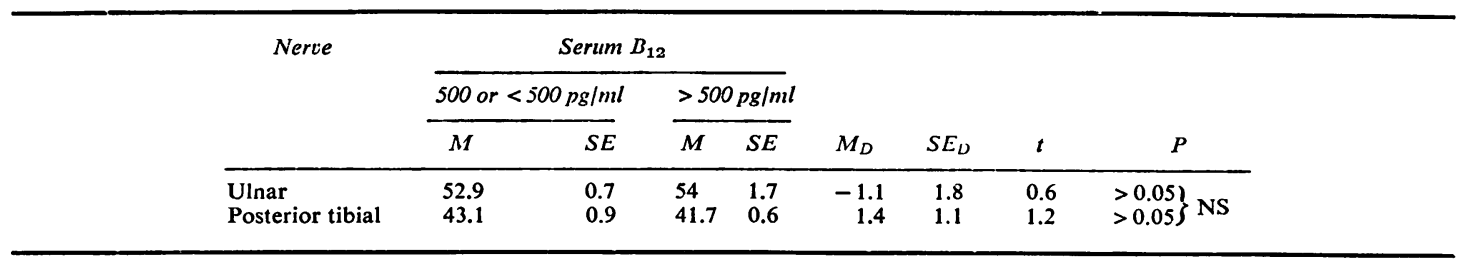

M: Mean; SE: Standard error; $\mathbf{M}_{\mathrm{D}}$ : Mean difference; $\mathrm{SE}_{\mathrm{D}}$ : Standard error of mean difference.

To determine if the conduction velocities were related to age, motor conduction velocities in two groups of patients were divided according to ages: (a) 17 to 35 , and (b) 36 to 58 years. It can be seen from Table 5 that the difference between the conduction velocities in the two age groups was not statistically significant. Table 6 shows the relation between serum DPH level and motor nerve conduction velocities. Serum DPH levels were divided into two groups: (a) those with serum DPH $20 \mu \mathrm{g} / \mathrm{ml}$ or less, and (b) those with serum DPH more than $20 \mu \mathrm{g} / \mathrm{ml}$. In the ulnar nerve no significant differences in velocities were noted in the two groups of patients. The posterior tibial nerve conduction velocities were significantly slower in group $b$ than in group a. We did not note any significant correlation between serum folate (Table 7) or cyanocobalamin (Table 8) levels and motor nerve conduction velocities in our patients.

\section{DISCUSSION}

Our study convincingly demonstrated impairment of posterior tibial motor nerve conduction in patients on prolonged (10 years or more) DPH treatment and in those with high (above
$20 \mu \mathrm{g} / \mathrm{ml}$ ) serum DPH level. These observations suggested subclinical distal neuropathy in the legs. Hopf (1968) and Birket-Smith and Krogh (1971) described reversible peripheral nerve dysfunction associated with short-term toxic doses of DPH. Peripheral nerve dysfunction after long-term DPH has been reported by Lovelace and Horwitz (1968), DeCastro et al. (1972), Encinoza (1974), and Eisen and associates (1974).

Clinical evidence of peripheral neuropathy as demonstrated by absent ankle reflexes was present in only three patients $(8.5 \%)$ in our series. In the report by Lovelace and Horwitz (1968), nine $(18 \%)$ of 50 patients on prolonged DPH treatment (five or more years) had absent ankle reflexes. In the series by Eisen $e t$ al. (1974), $12(27 \%)$ of 45 patients had absent ankle reflexes and eight patients showed sensory impairment. Therefore, the incidence of clinical peripheral neuropathy in our patients was much lower than that described by Lovelace and Horwitz (1968) and Eisen et al. (1974). Furthermore, we could not confirm the slowing of nerve conduction velocity and prolonged distal motor latency in the upper limbs reported by Lovelace and Horwitz (1968), DeCastro et al. (1972), and Eisen et al. (1974) respectively. As to the special 
predilection of DPH for the peripheral nerves in the legs, we have no satisfactory explanation. It is, however, generally well known that, in most of the toxic-metabolic neuropathies, the peripheral nerves in the lower limbs are affected preferentially.

The pathogenesis of DPH-induced peripheral nerve dysfunction remains unknown. DPH appears to have both a reversible acute toxic effect on the peripheral nerves and a long-term effect after prolonged treatment. The animal experiments of Toman (1949) and Morrell et al. (1958) demonstrated a depressant effect of DPH on peripheral nerve. Korey (1951) also demonstrated an inhibitory action of DPH on the giant axon of the squid which was made hyperexcitable by low calcium and magnesium. In discussing the pathogenesis of DPH-induced neuropathy, Eisen et al. (1974) favoured a primary axonal degenerating neuropathy. Subnormal serum folate as demonstrated in our patients is known to occur in individuals who had been on DPH treatment (Reynolds et al., 1969). Eisen et al. (1974), however, did not observe low serum folate values in their patients. Subnormal folate level has been implicated in the genesis of peripheral neuropathy in association with megaloblastic anaemia and DPH treatment (Long et al., 1963; Hansen et al., 1964). We agree with Lovelace and Horwitz (1968) that there is no association between peripheral nerve dysfunction after DPH treatment and low serum folate level (Table 7).

Although we have noted a significant correlation among several variables such as duration of
DPH treatment, motor nerve conduction velocities in the legs, and serum DPH and folate levels, the incidence of overt peripheral neuropathy in our patients on DPH treatment is very low.

\section{REFERENCES}

Birket-Smith, E., and Krogh, E. (1971). Motor nerve conduction velocity during diphenylhydantoin intoxication. Acta Neurologica Scandinavica, 47, 265-271.

DeCastro, J. H. X., Acosta, M. L., Sica, R. E. P., and Guereio, N. (1972). Sensory and motor nerve conduction velocity in long-term diphenylhydantoin therapy. Arquivos Neuro-Psiquiatria (Sao Paulo), 30, 215-220.

Eisen, A. A., Woods, J. F., and Sherwin, A. L. (1974). Peripheral nerve function in long-term therapy with diphenylhydantoin. Neurology (Minneap.), 24, 411-417.

Encinoza, O. (1974). Nerve conduction velocity in patients on long-term diphenylhydantoin therapy. Epilepsia, 15, 147-154.

Hansen, H. A., Nordquist, P., and Sourander, P. (1964). Megaloblastic anemia and neurologic disturbance combined with folic acid deficiency. Acta Medica Scandinavica, 178, 243-251.

Hopf, H. C. (1968). Effect of diphenylhydantoin on peripheral nerves in man. Electroencephalography and Clinical Neurophysiology, 25, 411.

Korey, S. R. (1951). Effect of dilantin and mesantoin on the giant axon of the squid. Proceedings of the Society of Experimental Biology, 76, 297-299.

Long, M. T., Childress, R. H., and Bond, W. H. (1963). Megaloblastic anemia associated with the use of anticonvulsant drugs. Neurology (Minneap.), 13, 697-702.

Lovelace, R. E., and Horwitz, S. J. (1968). Peripheral neuropathy in long-term diphenylhydantoin therapy. Archives of Neurology, 18, 69-77.

Morrell, F., Bradley, W., and Ptashne, M. (1958). Effect of diphenylhydantoin on peripheral nerve. Neurology (Minneap.), 8, 140-144.

Reynolds, E. H., Preece, J., and Chanarin, I. (1969). Folic acid and anticonvulsants. Lancet, 1, 264-265.

Toman, J. E. P. (1949). The neuropharmacology of antiepileptics. Electroencephalography and Clinical Neurophysiology, 1, 33-44. 